\title{
$\mathrm{HBsAg}$ 소실 후 경구 핵산유사체를 중단한 만성 $\mathrm{B}$ 형간염의 혈청 재양전 및 급성 악화
}

조혜정, 신승각, 권오상, 김주현, 김연수 가천대학교 길병원 내과

\section{Seroreversion and Acute Decompensation in Chronic Hepatitis B after Discontinuation of Oral Nucleotide Analog in the Patients Achieving HBsAg Loss}

Hye Jeong Cho, Seung Kak Shin, Oh Sang Kwon, Ju Hyun Kim and Yun Soo Kim

Department of Internal Medicine, Gachon University Gil Medical Center, Incheon, Korea

Although rare patients with chronic hepatitis B can achieve HBsAg loss on oral nucleos(t)ide analog (NA), the optimal timing of stopping oral NAs safely has been considered when HBsAg and HBV DNA are negative in the serum because HBsAg loss induced by nucleos(t)ide analogs (NAs) appears to be durable if immunosuppressive therapy or chemotherapy are not done. On the other hand, the author experienced a case of HBsAg seroreversion and acute decompensation after the discontinuation of NA in a patient with HBsAg loss. This rare case highlights the need for the close monitoring of patients who achieved HBsAg loss and stopped NA. (Korean J Gastroenterol 2020;76:256-260)

Key Words: Hepatitis B virus; Functional cure; HBsAg loss; HBsAg reversion; Nucleos(t)ide analogues

\section{서 론}

만성 B형간염에 대한 치료는 인터페론을 시작으로 경구용 항바이러스 치료제들이 사용되면서 많은 발전이 이루어졌다 그러나 현재까지의 만성 B형간염의 치료제는 바이러스의 증 식을 억제할 뿐, 바이러스 자체를 사멸시킬 수 없기 때문에 완치를 기대하기가 어려운 상황이다. ${ }^{1}$

최근 미국과 유럽 간학회의 공동 컨퍼런스에서는 만성 $\mathrm{B}$ 형 간염의 완전한 치유를 혈액 내의 HBV DNA 미검출, $\mathrm{HBsAg}$ 의 소실, 간세포 내에 covalently closed circular DNA (cccDNA) 및 숙주 유전자의 integrated HBV DNA 소실로 정의하였다. ${ }^{2}$ 그러나 현재로서는 이러한 완치를 달성하기 어
렵기 때문에 그 다음으로 제시된 목표가 바로 '기능적 치유 (functional cure)'이다. 기능적 치유의 정의는 바이러스 치료 종료 후 anti-HBs의 혈청 전환 동반 유무와 상관없이 혈청 $\mathrm{HBsAg}$ 과 HBV DNA의 지속적인 소실이다. 비록 $\mathrm{CCCDNA}$ 가 존재할 수 있지만, 치료 종료 후 $\mathrm{HBV}$ 의 재발이 없으며, 간 손상이 진행되지 않아 간경변증이나 간세포암의 위험이 감소 하는 것을 의미한다. ${ }^{2-4}$

$\mathrm{HBsAg}$ 소실은 오랫동안 B형간염 치료의 이상적인 목표였 으며, 현재에도 전 세계의 여러 가이드라인에서 치료 종료 시 점으로 권고하고 있다. 하지만 경구용 항바이러스 치료에서 $\mathrm{HBsAg}$ 소실은 0-3.2\%/년 빈도로 나타나고 있고, 아시아인에 게서는 특히 드문 것으로 보고되고 있다. ${ }^{5-7}$ 따라서 이런 드문

Received August 1, 2020. Revised August 19, 2020. Accepted August 19, 2020.

(C) This is an open access article distributed under the terms of the Creative Commons Attribution Non-Commercial License (http://creativecommons.org/licenses/ by-nc/4.0) which permits unrestricted non-commercial use, distribution, and reproduction in any medium, provided the original work is properly cited.

Copyright (c) 2020. Korean Society of Gastroenterology.

교신저자: 김연수, 21565 , 인천시 남동구 남동대로774번길 21 , 가천대학교 길병원 내과

Correspondence to: Yun Soo Kim, Department of Internal Medicine, Gachon University Gil Medical center, 21 Namdong-daero 774beon-gil, Namdong-gu, Incheon 21565,

Korea. Tel: +82-32-460-3778, Fax: +82-32-460-3778, E-mail: kimys@gilhospital.com, ORCID: https://orcid.org/0000-0003-2380-1217

Financial support: None. Conflict of interest: None. 
빈도로 인해, 항바이러스제 사용 후 $\mathrm{HBsAg}$ 소실된 환자에서 항바이러스제를 중단하고 장기적 예후를 보는 연구가 매우 어 렵다.

최근 국내 환자를 대상으로 한 $\mathrm{Kim}$ 등 $^{6}$ 의 연구 결과에서는 경구 항바이러스 치료 후 $\mathrm{HBsAg}$ 소실은 $0.33 \%$ /년의 빈도로 나타났고, $\mathrm{HBsAg}$ 역가가 다시 상승하는 경우는 110명 중 8명이 있었다. 그러나 이들 HBsAg 역가 상승은 0.05-1.00 $\mathrm{IU} / \mathrm{mL}$ 였고 7 명은 다시 음전 되었으며, 1 명은 $1 \mathrm{IU} / \mathrm{mL}$ 의 아 주 낮은 level로 양전이 유지되는 경과를 보이며 재치료는 필 요하지 않았다. ${ }^{6}$ 이렇듯 현재까지 $\mathrm{HBsAg}$ 소실 후 장기적 예 후가 좋은 것으로 알려진 반면, 저자들은 $\mathrm{HBsAg}$ 소실이 일어 난 환자에게서 경구 항바이러스제를 중단 후 $\mathrm{HBsAg}$ 양성으 로 혈청 재전환과 함께 경구 항바이러스제를 다시 시작해야 할 정도의 비대상성 간부전을 동반한 $\mathrm{B}$ 형간염의 재활성화를 경험하였기에 문헌고찰과 함께 보고하는 바이다.

\section{증 례}

61세 남자 환자가 5일 전부터 발생한 육안적 갈색뇨를 주 소로 외래로 내원하였다. 동반 증상으로 피곤함과 소화불량을 호소하였다. 환자는 만성 B형간염으로 2004년 4월부터 lamivudine을 복용하다가 내성이 생겨 2006년 8월부터는 adefovir dipivoxil로 변경하여 유지하고 있었다. 2007년 10월부 터는 $\mathrm{HBV}$ DNA가 검출되지 않은 상태가 유지되었으며, 2014년에 HBsAg 역가는 $86.97 \mathrm{IU} / \mathrm{mL}$ 였다. 내원 5개월 전인 2019년 7월, $\mathrm{HBsAg}$ 이 검출되지 않고 $\mathrm{HBsAg}$ 역가가 $0.82 \mathrm{IJ} / \mathrm{mL}$ 로 $\mathrm{HBsAg}$ 소실기로 판단되어 adefovir dipivoxil 복용을 중 단하였다. 당시 $\mathrm{HBeAg}$ 음성, $\mathrm{HBeAb}$ 음성, $\mathrm{HBV} \mathrm{DNA}<15$ $\mathrm{IU} / \mathrm{mL}$ 였고 $\mathrm{ALT} 21 \mathrm{U} / \mathrm{L}, \mathrm{AST} 29 \mathrm{U} / \mathrm{L}$, 총 빌리루빈 1.58 $\mathrm{mg} / \mathrm{dL}$, 알부민 $3.8 \mathrm{~g} / \mathrm{dL}$ 였다.

환자는 2005년 6월 $2.8 \mathrm{~cm}$ 간세포암이 진단되어 경동맥화학 색전술(transarterial chemoembolization therapy, TACE)을 시행 받았고, 이후 간세포암의 재발이 반복되어 총 7차례의 $\mathrm{TACE}$ 를 시행 받았다. 2015년 3월 마지막 TACE와 방사선 병합치료를 마지막으로 이번 내원 당시까지 약 5년간 간세포암 의 재발은 없었다.

내원 당시 활력징후는 혈압 $143 / 83 \mathrm{mmHg}$, 심박수 90회/분, 호흡수 18 회/분, 체온 $36.7^{\circ} \mathrm{C}$ 였다. 신체 검사에서 의식은 명 료하였으나 급성 병색을 보였고 전신에 황달이 있었다. 흥부 진찰에서 심음 및 호흡음은 정상이었다. 복부 진찰에서 복부 팽만은 없었고 장음은 정상이었으며, 간과 비장은 촉지되지 않았다. 복부 타진 시 압통 및 반동 압통이나 복막 자극 증상 은 없었고, 촉지되는 종괴는 없었다. 말초혈액 검사에서 혈색 소 $12.4 \mathrm{~g} / \mathrm{dL}$, 백혈구 $2,530 / \mathrm{mm}^{3}$, 분획 중성구 $80.8 \%$, 혈소
판 $52,000 / \mathrm{mm}^{3}$ 였으며, 요검사에서는 빌리루빈 3+, red blood cells 3-5개/high power field였다. 혈청생화학 검사에서 총 빌리루빈 $16.36 \mathrm{mg} / \mathrm{dL}$, 알부민 $3.4 \mathrm{~g} / \mathrm{dL}, \mathrm{AST}$ 1,292 U/L, ALT 951 U/L, GGT 141 U/L, ALP 258 U/L, 혈액 응고 검사 에서 프로트롬빈 시간 15.1초(참고치 9.5-13초), 혈액요소질 소 $15.5 \mathrm{mg} / \mathrm{dL}$, 크레아티닌 $1.27 \mathrm{mg} / \mathrm{dL}$ 였다. 바이러스 표지 자는 $\mathrm{HBsAg}$ 양성, $\mathrm{HBeAg}$ 양성, $\mathrm{IgM} \mathrm{HAV}$ 음성, $\mathrm{HBV}$ $\mathrm{DNA}$ 는 51,700,000 IU/mL였고, $\mathrm{AFP}$ 는 $8.3 \mathrm{ng} / \mathrm{mL}$ 였다. B형 간염 재활성화로 판단하였고, 입원하여 tenofovir alafenamide를 고려하였으나 국내 보험기준상 간세포암 환자에서는 사용할 수가 없어 tenofovir disoproxil fumarate (TDF) $300 \mathrm{mg}$ 으로 투약을 시작하였다. 입원 당시 시행한 초음파에서는 여

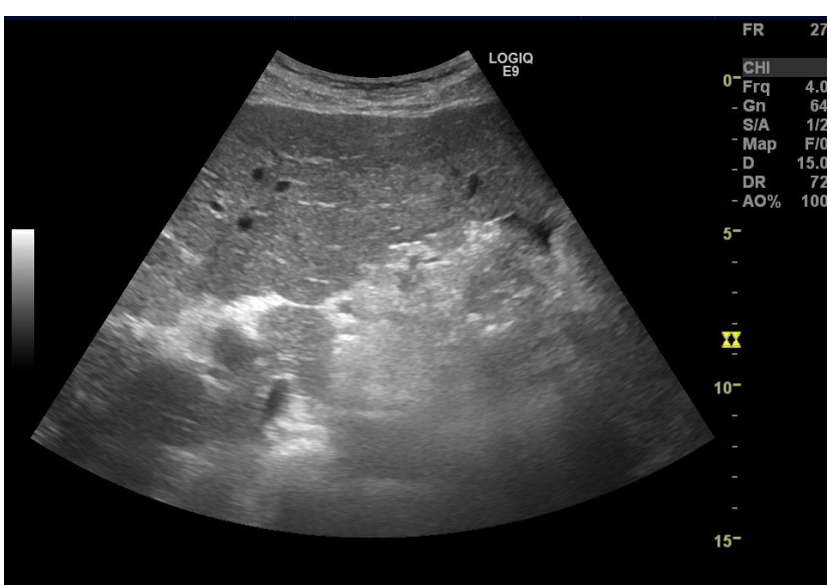

Fig. 1. Abdominal ultrasonography performed immediately after hospitalization. Coarse echo of the liver parenchyma and nodularity of liver surface can be observed. There is no recurrence of hepatocellular carcinoma or ascites.

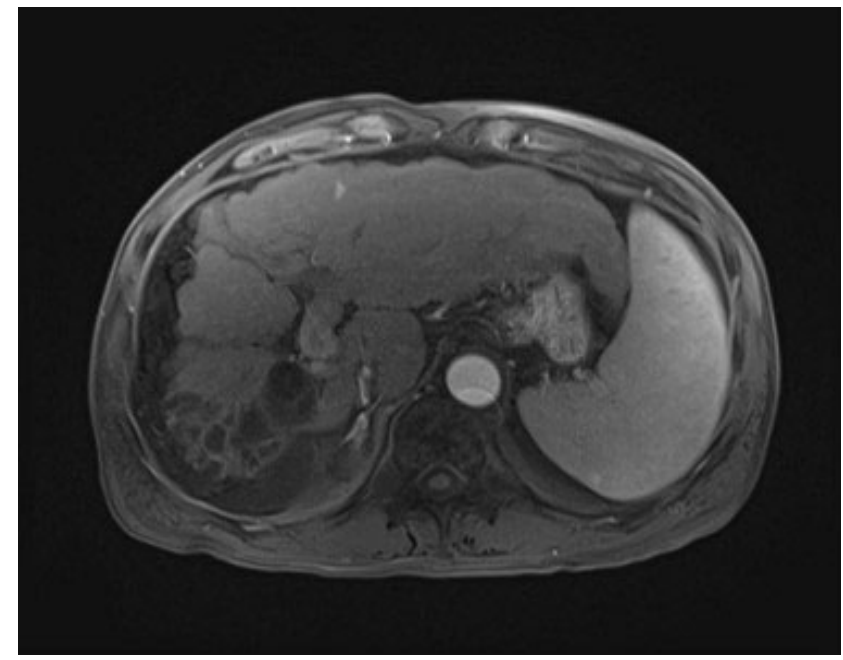

Fig. 2. Liver dynamic magnetic resonance imaging showed no evidence of tumor recurrence. 
전히 간경변이 있었고, 복수나 간세포암 재발은 없었다(Fig. 1). 간의 MRI를 시행하여 간세포암의 재발은 없음을 확인하였 다(Fig. 2). 이후 입원 중 복부 팽만감을 호소하여 시행한 추적 복부 초음파에서 중등도의 복수가 발생하였다(Fig. 3).

$\mathrm{TDF}$ 투약 후 간기능 수치는 점차 호전을 보였고, 1 달간의 입원 치료 진행 후 퇴원하였으며, 외래 경과 관찰 중 시행한 검사에서 $\mathrm{HBV}$ DNA $1,730 \mathrm{IU} / \mathrm{mL}$, 총 빌리루빈 $2.85 \mathrm{mg} / \mathrm{dL}$, AST $54 \mathrm{U} / \mathrm{L}, \mathrm{ALT} 32 \mathrm{U} / \mathrm{L}$, 프로트롬빈 시간 13.4초로 호전되었 다(Table 1). 환자는 현재 특별한 증상 없이 TDF 복용을 지속하 며 외래 추적 관찰 중이다.

\section{고 찰}

혈청 $\mathrm{HBsAg}$ 은 $\mathrm{CCCDNA}$ 의 유용한 대리지표로, $\mathrm{CCCDNA}$ 는 간세포 내에서 바이러스 증식의 주형 역할을 하기 때문에 $\mathrm{CCCDNA}^{\mathrm{O}}$ 감소는 지속적인 치료반응과 연관되어 있다. ${ }^{8}$ 따 라서 $\mathrm{cccDNA}$ 의 대리지표인 $\mathrm{HBsAg}$ 를 측정함으로써 만성 $\mathrm{B}$ 형간염의 치료반응과 연관성을 생각할 수 있고, 최근 $\mathrm{HBsAg}$ 의 정량법이 발달함에 따라 $\mathrm{HBsAg}$ 의 혈청 농도로 치료반응 및 예후를 예측할 수 있다는 연구 결과가 활발히 축적되고
있는 상황이다. 실제로 전 세계적으로 만성 $\mathrm{B}$ 형간염에 대한 치료 가이드라인은 $\mathrm{HBsAg}$ 소실을 이상적인 종료 시점으로 정하고 있으며, 경구용 항바이러스제 복용 후 나타난 $\mathrm{HBsAg}$ 소실은 인터페론 치료나 자발적으로 소실된 환자들과 비슷하 게 유지되는 것으로 보고되고 있다. ${ }^{9}$ 이처럼 $\mathrm{HBsAg}$ 소실이 일어난 환자의 장기적 예후는 매우 좋은 것으로 알려져 있어 유용한 종료 시점임은 분명하다.

최근 미국과 유럽의 공동 컨퍼런스에서 정의한 기능적 치 유는 바이러스 치료 종료 후 anti-HBs의 혈청 전환 동반 유무 와 상관없이 혈청 $\mathrm{HBsAg}$ 과 $\mathrm{HBV} \mathrm{DNA}$ 의 지속적인 소실이 다. 여기서 $\mathrm{HBsAg}$ 의 소실은 최저검출한계(lower limit of detection) $0.05 \mathrm{IU} / \mathrm{mL}$ 이하로 정의하고 있다. 본 증례의 경 우 $\mathrm{HBsAg}$ 이 $0.05 \mathrm{IU} / \mathrm{mL}$ 이하가 아닌 $0.82 \mathrm{IU} / \mathrm{mL}$ 였으나, $100 \mathrm{IU} / \mathrm{mL}$ 미만의 경우 의미 있는 치료 종료 시점으로 볼 수 있다는 연구 결과가 있다. ${ }^{10}$ 따라서 가이드라인에 따른 엄 격한 HBsAg 소실과 항바이러스제의 치료 종료는 아니었지 만 다음과 같은 이유로 항바이러스제의 종료를 결정하였다. 첫째, $\mathrm{HBsAg}$ 이 검출되지 않고 $\mathrm{HBV} \mathrm{DNA}$ 가 10년 이상 검출 되지 않고 있으며, 둘째, 가천대학교 길병원에서 $\mathrm{HBsAg} 10$ $\mathrm{IU} / \mathrm{mL}$ 미만인 환자들에게서 치료 종료 후 재활성화는 경험하
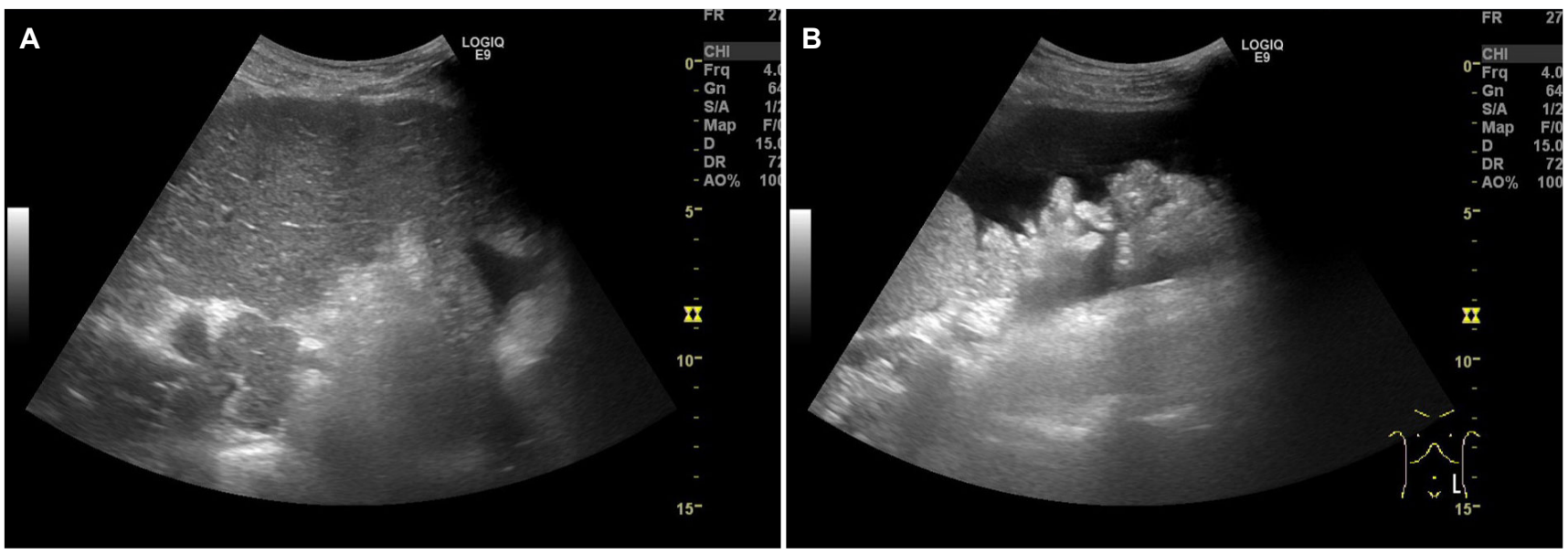

Fig. 3. The patient complained of abdominal distension, and follow-up ultrasonography was performed. (A) Nodular liver surface and (B) moderate ascites are observed.

Table 1. Change in the Liver Function after Admission to Hospital

\begin{tabular}{|c|c|c|c|c|c|c|c|c|}
\hline Hospital days & 1 & 5 & 14 & 19 & 23 & 33 & 58 (OPD) & 93 (OPD) \\
\hline $\mathrm{Tb}(\mathrm{mg} / \mathrm{dL})$ & 19.92 & 22.58 & 33.27 & 29.32 & 28.7 & 24.28 & 7.07 & 2.85 \\
\hline AST (U/L) & 1,068 & 561 & 169 & 167 & 155 & 180 & 104 & 54 \\
\hline $\operatorname{ALT}(\mathrm{U} / \mathrm{L})$ & 865 & 501 & 155 & 106 & 102 & 111 & 74 & 32 \\
\hline Albumin (g/dL) & 3.4 & 2.9 & 3.2 & 2.8 & 2.7 & 2.8 & 3.0 & 3.3 \\
\hline PT (sec) & 15.1 & 17.2 & 16.8 & 18.3 & 18.5 & 16.0 & 12.6 & 13.4 \\
\hline
\end{tabular}

OPD, out patients department; Tb, total bilirubin; AST, aspartate aminotransferase; ALT, alanine aminotransaminase; PT, prothrombin time. 
지 못하였기에 투약 종료를 결정하였다.

본 증례의 경우 투약 종료 후 12 주 후의 추적 혈액 검사에 서 별다른 이상이 없던 중, 종료 후 5 개월에 증상과 함께 B형 간염의 재활성화가 확인되어 기능적 치유에 실패하였고, 다시 경구 항바이러스제를 시작하였다. B형간염의 기능적 치유 후 항암치료나 면역억제치료 등에 의해 유발된 B형간염의 재활 성화는 많은 보고가 있다. 그러나 본 증례처럼 $\mathrm{HBsAg}$ 소실 후 항바이러스제 종료 후에 자연적으로 급성 재발되어 다시 치료가 필요하였던 증례는 찾아볼 수 없었다.

본 증례는 향후 기능적 치유에 대한 다음과 같은 의문과 추가 연구의 필요성을 제기하고 있다. 첫 번째, 기능적 치유는 치료 종료 후 최소 6개월 간격으로 HBsAg 소실이 2번 이상 확인되며, HBV DNA가 검출되지 않는 것을 가장 좋은 지표 로 삼고 있다. ${ }^{10}$ 또한 HBsAg 소실 후 6-12개월 이상 치료를 유지한 후 항바이러스 치료를 종료하면 $\mathrm{HBsAg}$ 의 재양전을 피할 수 있다고 보고되었다. ${ }^{11}$ 그러나 과연 이러한 방법이 B형 간염의 재활성화를 배제할 수 있는 지표인지에 대해서는 장기 간의 연구가 필요하다.

두 번째, 본 증례의 경우 간세포암과 간경변을 가진 환자 로, 간세포암의 경우에는 B형간염의 치료 종료시점에 대한 가 이드라인을 찾을 수 없었다. 그러나 간경변이 동반된 만성 $\mathrm{B}$ 형간염 환자의 경우에는 유렵간학회와 미국간학회의 지침은 $\mathrm{HBsAg}$ 소실 여부에 대한 언급은 없이 무기한 경구 항바이러 스제 치료를 권장하고 있다.,4,12 그러나 $\mathrm{Kim}^{\text {등 }}{ }^{6}$ 의 연구에 따 르면 경구 항바이러스 치료 후 HBsAg 음전이 일어난 110명 의 환자 중 34 명이 간경변이 동반된 환자였으며, 앞에서 언급 하였듯이 급성 재발되어 다시 치료가 필요하였던 환자는 없었 다. 그러나 본 증례에서와 같이 여유 간기능이 적은 간경변이 나 간세포암 환자의 경우 B형간염의 재활성화는 치명적 결과 를 초래할 수 있기 때문에 치료 종료 시점에 대해서 주의가 더 필요하다. 현재로서는 간경변과 간세포암이 동반된 만성 $\mathrm{B}$ 형간염 환자에게서는 $\mathrm{HBsAg}$ 뿐만 아니라 다른 치유를 예 측할 수 있는 여러 인자들을 고려해 치료 종료를 종합적으로 판단해야 할 필요가 있다.

세 번째, $\mathrm{HBsAg}$ 소실이 확인된 환자에게서 추적 간격에 대한 문제이다. 현재까지 연구에서는 HBsAg 소실 후 항바이 러스 치료 종료 후 예후가 좋을 것으로 예상되었기 때문에 학회에서 제시된 별다른 가이드라인이 없다. 본 증례에서는 3 개월 후 환자가 내원하였을 때에는 간기능이 정상이었으나 투약 종료 후 5 개월만에 간기능의 급속 악화와 B형간염의 재 양전이 관찰되었다. 따라서 항바이러스 치료 종료 후 추적 간 격을 더 짧게 하고 각종 바이러스 혈청 표지자를 검사하는 것이 타당할 것으로 생각되며 이에 대한 연구도 필요하다.

네 번째, HBsAg 소실이 치료 종결 시점으로 충분한 가치
가 확인이 되었는지에 대한 문제이다. Kim 등 ${ }^{6}$ 의 연구에서 이미 HBsAg 소실 후 약제를 종료한 경우라도 $\mathrm{HBsAg}$ 재양 전이 일어날 수 있다는 것이 보고되었다. 비록 재치료를 필요 로 하는 경우는 없었으나, 이는 B형간염의 급성 악화가 초래 될 가능성이 있다는 것을 시사하고 있다. 따라서 치료 종료에 참고할 수 있는 다른 지표들에 대해서도 고려해 보아야 한다. $\mathrm{HBeAg}$ 음성 만성 $\mathrm{B}$ 형간염 환자에서 anti-HBC 정량법이 기 능적 치유의 예측인자로 이용될 수 있고, ${ }^{13} \mathrm{HBV}$ core-related antigen은 B형간염 바이러스의 C 유전자에서 만들어지는 $\mathrm{HBcAg}, \mathrm{HBeAg}, \mathrm{p} 22 \mathrm{cr}$ 단백을 측정하는 인자로 $\mathrm{cccDNA}$ 수치와 상관관계가 있음이 보고되었다. ${ }^{14}$ 또한, 혈청 $\mathrm{HBV}$ $\mathrm{RNA}$ 는 $\mathrm{CCCDNA}$ 의 전사 활동도를 반영하는 표지자로 사용될 수 있고, HBV core-related antigen 항바이러스제 치료 시 $\mathrm{HBeAg}$ 혈청 전환의 예측인자로, 항바이러스제 중단 후 $\mathrm{HBsAg}$ 재양전의 예측인자로 사용될 수 있다고 보고하였 다. ${ }^{13,15}$ 이처럼 $\mathrm{HBsAg}$ 외에도 여러 인자들이 만성 B형간염 치료의 예측인자로 보고되고 있지만, 과연 $\mathrm{HBsAg}$ 을 대치할 수 있을 정도의 유용성이 있는지에 대해서는 더 연구가 필요 하다.

결과적으로 현시점에서는 항바이러스제로 치료하는 만성 $\mathrm{B}$ 형간염 환자에서 기능적 치유의 정의는 가이드라인에서 제 시한 바와 같이 $\mathrm{HBsAg}$ 을 적어도 6개월 간격으로 확인해 두 번 이상 음전을 확인하고, $\mathrm{HBsAg}$ 의 역가도 $0.05 \mathrm{IU} / \mathrm{mL}$ 이하 인 것을 6개월 간격으로 두 번 이상 확인해야 할 것으로 생각 된다. 향후 $\mathrm{HBsAg}$ 보다 더 정확한 지표가 발견될 때까지는 이 같은 가이드라인에 따라 항바이러스 치료의 종료 시점을 정할 수밖에 없다. 그러나 설사 유용한 새로운 지표들이 발견 된다 하더라도 간경변이나 간세포암 환자에서도 적용할 수 있 는지에 대해서는 조심스러운 연구가 필요하다.

\section{REFERENCES}

1. Calvaruso V, Craxì A. Fibrosis in chronic viral hepatitis. Best Pract Res Clin Gastroenterol 2011;25:219-230.

2. Cornberg M, Lok AS, Terrault NA, Zoulim F; 2019 EASL-AASLD HBV Treatment Endpoints Conference Faculty. Guidance for design and endpoints of clinical trials in chronic hepatitis B - report from the 2019 EASL-AASLD HBV treatment endpoints conference ${ }^{\ddagger}$. J Hepatol 2020;72:539-557.

3. European Association for the Study of the Liver, European Association for the Study of the Liver. EASL 2017 clinical practice guidelines on the management of hepatitis B virus infection. J Hepatology 2017:67;370-398.

4. Terrault NA, Lok ASF, McMahon BJ, et al. Update on prevention, diagnosis, and treatment of chronic hepatitis B: AASLD 2018 hepatitis B guidance. Hepatology 2018;67:1560-1599.

5. European Association For The Study Of The Liver. EASL clinical 
practice guidelines: management of chronic hepatitis $B$ virus infection. J Hepatol 2012;57:167-185.

6. Kim GA, Lim YS, An J, et al. HBsAg seroclearance after nucleoside analogue therapy in patients with chronic hepatitis B: clinical outcomes and durability. Gut 2014;63:1325-1332.

7. Cornberg M, Höner Zu Siederdissen C. HBsAg seroclearance with NUCs: rare but important. Gut 2014;63:1208-1209.

8. Zoulim F. New insight on hepatitis B virus persistence from the study of intrahepatic viral cccDNA. J Hepatol 2005;42:302-308.

9. Martinot-Peignoux M, Lapalus M, Asselah T, Marcellin P. HBsAg quantification: useful for monitoring natural history and treatment outcome. Liver Int 2014;34 Suppl 1:97-107.

10. Cornberg M, Wong VW, Locarnini S, Brunetto M, Janssen HLA, Chan HL. The role of quantitative hepatitis $B$ surface antigen revisited. J Hepatol 2017;66:398-411.

11. Yip TC, Wong GL, Wong VW, et al. Durability of hepatitis B surface antigen seroclearance in untreated and nucleos(t)ide analogue-treated patients. J Hepatol 2018:68;63-72.

12. Terrault NA, Bzowej NH, Chang KM, et al. AASLD guidelines for treatment of chronic hepatitis B. Hepatology 2016;63:261-283.

13. Hu HH, Liu J, Chang CL, et al. Level of hepatitis $B(H B)$ core antibody associates with seroclearance of HBV DNA and HB surface antigen in $\mathrm{HB}$ e antigen-seronegative patients. Clin Gastroenterol Hepatol 2019;17:172-181.e1.

14. Testoni B, Lebossé F, Scholtes C, et al. Serum hepatitis B core-related antigen (HBcrAg) correlates with covalently closed circular DNA transcriptional activity in chronic hepatitis B patients. J Hepatol 2019;70:615-625.

15. Liu F, Wang XW, Chen L, Hu P, Ren H, Hu HD. Systematic review with meta-analysis: development of hepatocellular carcinoma in chronic hepatitis B patients with hepatitis B surface antigen seroclearance. Aliment Pharmacol Ther 2016;43:1253-1261. 